\title{
Periodic Revival or Continuation of the Ancient Military Tradition? ANOTHER LOOK AT THE QUESTION of THE KATÁFRAKTOI In THE ByZANTine ArMY ${ }^{1}$
}

The historiography of the $20^{\text {th }}$ century used to pay much attention to the appearance of heavily armoured cavalry as a symptom of transition from the ancient world to Middle Ages ${ }^{2}$. There are however still some problems concerning the character of the different kinds of armoured cavalry, its genesis and continuity in the Early Byzantine period. Ancient written sources indicate that the socalled catafracti (Gr. katáfraktoi), catafractarii (Gr. katafraktárioi) and clibanarii (Gr. klibabárioi), the ancient heavy armoured cavalry, were present on the battlefields of the ancient world from the Hellenistic period to the Late Antiquity. According to Greek and Roman writers, the catafracti and clibanarii were employed by the Parthians; catafracti formed a part of the Seleucid cavalry; detachments of catafracti

1 This study constitute an enhanced version of my earlier text printed in Polish Katáfraktoi - ciężkozbrojna jazda Cesarstwa Bizantyńskiego jako kontynuacja antycznych catafracti i clibanarii, ZNUJ 132, 2005, p. 7-21, and contains a results of my further research concerning the question of heavy armoured cavalry in Byzantium. I need to express my gratefulness to Patryk Skupniewicz for sharing his library with me.

2 See e.g. E. DARKó, Le rôle des peuples nomades cavaliers dans la transformation de l'Empire romain aux premiers siècles du moyen âge, B 18, 1948, p. 85-97; L. White, Medieval Technology and Social Change, Oxford 1962, p. 1-38; B. BACHRACH, The Rise of Armorican Chivalry, TC 10, 1967, p. 166-171; IDEM, Charles Martel, Mounted Shock Combat, the Stirrup and Feudalism, SMRH 7, 1970, p. 47-75; L. WhITE, The Crusades and the Technological Thrust of the West, [in:] War, Technology and Society in the Middle East, ed. V.J. Parry, M.E. Yapp, London 1975, p. 98-99; J. Bérenger, L'influence des peuples de la steppe (Huns, Mongols, Tartares) sur la conception européene de la guerre de mouvement et l'emploi de la cavalerie (Ve-XVII siècle), RIHM 49, 1980, p. 33-50; F. CARDINI, Alle radici della cavalleria medievale, Firenze 1981, passim; J. FlORI, L'ideologie du glaive. Préhistoire de la chevalerie, Geneve 1983, passim; IDEM, Les origines de la chevalerie, CCM 27, 1984, p. 359-365; B. ВACHRACH, Caballus and Caballarius in Medieval Warfare, [in:] The Study of Chivalry: Resources and Approaches, ed. H. Chickering, T.H. Seiler, Kalamazoo 1988, p. 173-211; А.М. ХАзанов, Роль кочевников евразийских степей в истории военного искусства, [in:] Роль номадов евразийских степей в развитии мирового военного искусства. Научные чтения памяти Н.Э. Масанова: сборник материалов международной научной конференции 22-25 Апреля 2010 года, еd. И.В. ЕрОФЕВА, Б.Т. ЖАНАЕВ, Л.Е. МАСАНОВА, Алматы 2010, p. 8-26. 
and clibanarii served in the Roman army and they were also present in Sasanian Persia and Armenia ${ }^{3}$.

One should draw attention to the fact, that the relationship between catafracti and clibanarii is not clear. For example, the words clibanarius/clibanarii and catafractus/catafracti referring both to the Persian and Roman heavy-armoured horsemen, appeared in Roman sources recording events that took place in the $3^{\text {rd }}$ and $4^{\text {th }}$ century A.D. In this case the terms mentioned above were used interchangeably ${ }^{4}$. The problem is whether the catafracti and clibanarii were a Parthian, Persian or Roman unit defined by two names, or whether they represented two types of heavy cavalry. If the second possibility is true, the question arises what did the difference consist in ${ }^{5}$.

No thesis based on the assumption that the existence of the two names is due to the difference in rider's armour, weapon and equestrian equipment has been accepted so far. A contrary opinion, that there was no difference between those two formations, has been rejected as well. It was the equipment that used to be regarded as the main element which made it possible to distinguished the catafracti

3 D.T. Роттs, Cataphractus and kāmāndar: Some Thoughts on the Dynamic Evolution of Heavy Cavalry and Mounted Archers in Iran and Central Asia, BAI 21, 2012, p. 149-158; W.W. TARN, Hellenistic Military and Naval Developments, Cambridge 1930, p. 73-74; B. BAR-Kochva, The Seleucid Army. Organization and Tactics in the Great Campaigns, Cambridge 1976, p. 40, 42, 67, 74-75; G.A. KošELENKo, Les cavaliers parthes. Aspects de la structure sociale de la Parthie, DHA 6, 1980, p. 177-179; M. MieLCZAREK, Die parthische Panzerreiterei bei Carrhae. Aus den Studien über Plutarchus, Crassus XXIV-XXVII, FAH 4, 1988, p. 31-38; IDEM, Demonstracja wojskowa w Dafne w 166 r. p.n.e. a wyprawa Antiocha III Epifanesa na Wschód, AUL.FH 44, 1992, p. 3-12; M.P. Speidel, Riding for Caesar. The Roman Emperors' Horse Guards, London 1994, p. 154; В.П. Никоноров, К вопросу о парфянской тактике (на примере битвы при Каррах), [in:] Военное дело и средневековая археология Центральной Азии, ed. А.И. МАртынов et al., Кемерово 1995, p. 53-61; M. Mielczarek, Cataphracts - a Parthian Element in the Seleucid Art of War, [in:] Ancient Iran and the Mediterranean World. Electrum. Studies in Ancient History, ed. Е. DĄвRowA, Cracow 1998, p. 101-105; В.П. Никоноров, К вопросу о парфянском наследии в сасанидском Иране: военное дело, [in:] Центральная Азия от Ахеменидов до Тимуридов: археология, история, этнология, культура. Материаль международной научной конференции, посвященной 100-летию со дня рождения Александра Марковича Белениикого (Санкт-Петербург, 2-5 Ноября 2004 года), ed. IDEм, Санкт-Петербург 2005, p. 142-143; М.Я. Ольврихт, К вопросу о происхождении конницы катафрактов в Иранеи и Средней Азии, [in:] Роль номадов..., р. 66-85; В.П. Никоноров, К вопросу о вкладе кочевников Центральной Азии в военное дело античной циивилизации [in:] Роль номадов..., p. 46-47.

4 See e.g. Ammiani Marcellini Rerum gestarum libri qui supersunt, XVI, 10, 8; XIX, 7, 4; XXIV, 6, 8, ed. et trans. J.C. Rolfe, London 1935 (cetera: Ammianus Marcellinus). On Ammianus' military qualification see: G.A. CRUmP, Ammianus Marcellinus as a Military Historian, Wiesbaden 1975; N.J.E. Austin, Ammianus on Warfare: An Investigation into Ammianus' Military Knowledge, Brussels 1979; F. Trombley, Ammianus Marcellinus and Fourth-Century Warfare: a Protector's Approach to Historical Narrative, [in:] The Late Roman World and Its Historian. Interpreting Ammianus Marcellinus, ed. J.W. DRIJvers, D. HunT, New York 1999, p. 16-27; D. DEN Hengst, Preparing the Reader for War: Ammianus' Digression on Siege Engines, [in:] The Late Roman World..., p. 27-37.

5 M. Mielczarek, Cataphracti and Clibanarii. Studies on the Heavy Armoured Cavalry of the Ancient World, Łódź 1993, p. 9-10. 
from the clibanarii and to discover the similarities and differences between the two types of the cavalry. The question of the tactics deployed by the catafracti and clibanarii was passed over6.

A completely different methodological approach was proposed by a Polish scholar Mariusz Mielczarek. The solution worked out in his study Cataphracti and clibanarii. Studies on the Heavy Armored Cavalry of the Ancient World differs from those put forward usually by scholars dealing with the catafracti and clibanarii. According to him, the basic criterion of the catafracti and clibanarii distinction was not based on an analysis of the arms and armour used but rather on an attempt to determine the tactics characteristic of the both kinds of heavy armoured cavalry?

M. Mielczarek supposes, that the catafracti were a heavy armoured cavalry (this term derives from the Greek verb katafrássō - 'to enclose, wall up, to cover with armour') fighting in a deployed column order composed of a number of horsemen lines. The spear had been for a long time their main offensive weapon, held along the horse's flanks and freely wielded. The battle column order of the horsemen of this type was particularly effective against a deep array consisting of infantrymen. It seems that the catafracti were the response given by the eastern horsemen to the Macedonian phalanx. Probably they were created as a type of cavalry which would be able to oppose heavy - armoured Macedonian infantry. Their protective armour underwent a development. It became gradually longer and it covered, as

\footnotetext{
6 Ibidem, p. 10-11, 89. Yet, modern studies on catafracti and clibanarii are focused mainly on their panoply. See e.g. R.M. RatTenbury, An Ancient Armoured Force, CR 56, 1942, p. 113-116; L.A. Post, Cataphracts in Curtius, ClaW 18, 1946, p. 40; B. RuBIN, Die Entstehung der Kataphraktenreiterei im Lichte der chorezmischen Ausgrabungen, Hi 4, 1955, p. 264-283; J.W. EAdIE, The Development of Roman Mailed Cavalry, JRS 57, 1967, p. 161-173; А.М. ХАзАнов, Катафрактарии и их роль в истории военного искусства, ВДИ 1, 1968, p. 180-191; О. GAмвеR, Kataphrakten, Klibanarier, Normannenritter, JKSW 64, 1968, p. 7-44; А.К. Акишев, Костюм «золотого человека» и проблема катафрактария, [in:] Военное дело древних племен Сибири и Центральной Азии, еd. Ю.С. Худяков, Новосибирск 1981, p. 54-65; J.M. DieThaRT, P. DinTsis, Die Leontoklibanarier. Versuch einer archäologisch-papyrologischen Zusammenschau, [in:] Byzantios. Festschrift für Herbert Hunger zum 70. Geburststag, ed. W. Hörandner, J. Koder, O. Kresten, E. Trapp, Wien 1984, p. 67-79; M. Michalak, The Origins and Development of Sassanian Heavy Cavalary, FO 24, 1987, p. 76-84; P. BERNARD, Les nomades conquérants de lémpire grécobactrien. Réflexions sur leur identité ethnique et culturelle, CRAI 131, 1987, p. 759-762; H. Von GALL, Das Reiterkampfbild in der iranischen und iranisch beeinflussten Kunst partischer und sassanidischer Zeit, Berlin 1990, passim; O. HARL, Die Kataphraktarier im römischen Heer: Panegyrik und Realität, JRGZM 43, 1996, p. 601-627; V.P. Nikonorov, Cataphracti, Catafractarii and Clibanarii. Another Look at the Old Problem of Their Identification, [in:] Military Archaeology: Weaponry and Warfare in the Historical and Social Perspective. Materials of the International Conference 2-5 September 1998, ed. G.V. Vilnibahov et al., Saint Petersburg 1998, p. 131-138, J.J.V. SÁNCHEZ, Los regimentos de catafractos y clibanarios en la tardo antigüedad, CLR. AC 16, 1999, p. 397-415; IDEM, Catafracti y clibanari romanos. El desarrollo de cuerpos a caballo entre Occidente y Oriente, [in:] Boletín de la Academia de España en Roma 1999, Madrid 1999, p. 98-101; В.А. Дмитриев, Всадники в сверкающей брони. Военное дело сасанидского Ирана и история римско-персидских воин, Санкт-Петербург 2008, р. 60-84.

7 M. MielczareK, Cataphracti and Clibanarii..., p. 10.
} 
much as possible, the rider's body. This was followed by the development of horse's caparison along the same lines.

According to M. Mielczarek, the clibanarii deployed completely different tactics. The genesis of this term is uncertain. Similarly to catafracti, the clibanarii were heavy armoured horsemen, but they were used mainly against cavalry. As their main weapon they used a long spear held across the horse's neck, with its point placed to the left from the horse's head. Their main protective armour was a mail coat as well as additional coverings made of iron plates or scales. Due to the change in the use of the spear, carrying a shield became possible. Less attention was paid to the protection of the horse. Its metal caparison were replaced by the armour made of hardened leather or textile coverings reinforced by additional metal elements. Their tactics were distinct from that of the catafracti. They fought in the wedge-column order or in a similar one, forming the wedge's head. Further lines were composed of less heavy-armoured mounted archers?.

One cannot exclude the possibility that the same well trained horseman could function either as a catafractus or a clibanarius according to the tactics employed and there was no significant difference. He was a catafractus, when fighting in a column order against infantry, and a clibanarius when he fought against mounted warriors, as one of the soldiers at the head of the wedge-column order. Probably this is a correct interpretation of the expression catafractus (catafractarius) clibanarius documented by an inscription from Bithynia, which dates from the $4^{\text {th }}$ century A.D. ${ }^{10}$ The Notitia Dignitatum indicate that the difference between catafractarii and clibanarii in Roman army lay not necessary in their equipment and tactics but rather in the origin of the units. In this document we can observe that clibanarii, unlike catafractarii, were recruited in the East (e.g. equites primi clibanarii Parthi, equites Persae clibanarii, equites secundi clibanarii Parthi, cuneus equitum secundorum clibanariorum Palmirenorum $)^{11}$.

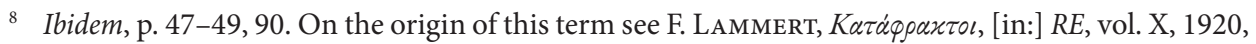
col. 2479; E.A. SopHocles, Greek Lexicon of the Roman and Byzantine Periods (from B.C. 146 to A.D. 1100), New York 1900, p. 649; H.G. LiddelL, R. Scotт, A Greek-English Lexikon, Oxford 1930, p. 920.

9 M. Mielczarek, Cataphracti and Clibanarii..., p. 49-50, 90.

10 M.P. Speidel, Cataphractarii, clibanarii and the Rise of the Later Roman Mailed Cavalry. A Gravestone from Claudiopolis in Bithynia, EA 4, 1984, p. 151-156; M. Mielczarek, Cataphracti and Clibanarii..., p. 50, 90. Vegetius' account indicate that catafracti were deployed against cavalry as well as infantry. See Flavi Vegeti Renati Epitoma Rei Militaris, III, 23, rec. C. LANG, Leipzig 1885. On Vegetius' military treatise see C. ZuCKerman, Sur la date du traité militaire de Vègéce et son destinataire Valentinien II, SCIsr 13, 1994, p. 67-94; T.D. Barnes, The Date of Vegetius, Phoe 33, 1979, p. 254-257; B. ВACHrach, The Practical Use of Vegetius' De re militari during the Early Middle Ages, [in:] IDEM, Warfare and Military Organization in Pre-Crusade Europe, Aldershot 2002, p. 239-255; Ch. Allmand, The De Re Militari of Vegetius in the Middle Ages and the Renaissance, [in:] Writing War. Medieval Literary Responses to Warfare, ed. C. SAUNDERs, F. Le Scaux, N. Thomas, Cambridge 2004, p. 15-29.

${ }^{11}$ J.W. Eadie, op. cit., p. 169-170; D. Hoffman, Das spätrömische Bewegungsheer und Notitia Dignitatum, vol. II, Düsseldorf 1970, p. 110-117; M. MielCZAReK, Cataphracti and Clibanarii..., p. 76-77; 
It should be remembered, that such cavalry constituted the elite of the army, and were, of course, extremely expensive to equip. Moreover, the service in a catafracti or clibanarii unit required considerable skills and constant military and equestrian practice, because the success of these formations on the battlefield depended on the discipline of horsemen who had to keep battle order. A breaking of the order could result in a disaster since a heavy armoured as well as an unhorsed warrior could easily be defeated by an infantryman or a mounted opponent ${ }^{12}$. It was for these reasons that only wealthy, experienced horsemen of long training were selected for that kind of service. A confirmation of this opinion can be found in a papyrus discovered in Egypt. According to this source a certain Serapion, who at the turn of the $4^{\text {th }} / 5^{\text {th }}$ centuries, after having served ten years in another cavalry unit, joined the catafractarii and after twenty months became a commander (decurio) of their detachment ${ }^{13}$.

The earliest information about catafracti in the Roman army is preserved from the times of the emperor Hadrian (117-138). An inscription of the prefect Marcus Agrippa discovered in Italy indicates the existence during the reign of this emperor of a detachment of heavy cavalry described as Ala Prima Gallorum et Pannoniorum catafractata, which was stationed in Moesia Inferior ${ }^{14}$. The coming into being of that formation seems to be due to the experience gained during the Parthian war conducted by Trajan in 114-117. Its appearance might be linked with Hadrian's military policy, who intended to remodel Roman cavalry on Sarmatian or rather Parthian pattern (as opposed to the Parthians, among the Sarmatian heavy cavalry horse armour was not fully developed; usually it was restricted to scale or plate peytral covering the horse chest) ${ }^{15}$. According to his intention this cavalry should have been able to fight like the Parthian and Armenian heavy-armoured horsemen and mounted archers ${ }^{16}$. In the $3^{\text {rd }}$ century A.D., the units of catafracti

D. Woods, The scholae palatinae and the Notitia Dignitatum, JRMES 7, 1996, p. 289-290; M. HeIL, Perser im Spätrömischen Dienst, [in:] Ërān ud Anērān. Studien zu den Beziehungen zwischen dem Sasanidenreich und der Mittelmeerwelt, ed. J. WiesehöFer, Ph. Huyse, München 2006, p. 152-154.

12 M. Mielczarek, Cataphracti and Clibanarii..., p. 50, 90; M.P. Speidel, Ancient Germanic Warriors. Warrior Styles from Trajan's Column to Icelandic Sagas, London 2004, p. 84-85, 142-143.

13 J.R. Rea, A Cavalryman's Career, A.D. 384(?)-401, ZPE 56, 1984, p. 79-88; M. MieLCZarek, Cataphracti and Clibanarii..., p. 79; C. Zuckerman, Le camp de Psōbthis/Sosteos et les catafractarii, ZPE 100, 1994, p. 201. On the term catafractarii see V.P. Nikonorov, Cataphracti, Cataphractarii, Clibanarii..., p. 132.

${ }_{14}$ Corpus Inscriptionum Latinarum, XI, 5632; M.M. Roxan, W. Eck, A Diploma of Moesia Inferior: 125 Iun. 1, ZPE 116, 1997, p. 195-196.

15 А.М. ХАзАнов, Очерки военного дела сарматов, Москва 1971, p. 86-87; A.K. Nefedкin, Sarmatian Armour According to Narrative and Archaeological Data, [in:] Arms and Armour as Indicators of Cultural Transfer. The Steppes and the Ancient World from Hellenistic Times to the Early Middle Ages, ed. M. Mode, J. Tubach, Wiesbaden 2006, p. 438; M. Mielczarek, Cataphracti and Clibanarii..., p. 101.

16 M. Mielczarek, Cataphracti and Clibanarii..., p. 73. See also A.N. Negin, Sarmatian cataphracti as prototypes for Roman equites cataphractarii, JRMES 6, 1995, p. 65-75. See also S. JAMES, The Impact of Steppe Peoples and the Partho-Sasanian World on the Development of Roman Military Equipment and Dress, 
and clibanarii became more numerous in the Roman army. Probably it was linked with Gallienus' intention to create of the mobile cavalry units ${ }^{17}$. Emperor Claudius II had at his disposal a detachment of 100 catafracti stationed in Dalmatia ${ }^{18}$, while Aurelian had 800 heavy-armoured horsemen ${ }^{19}$. Ammianus Marcellinus reports, that catafracti equites commanded by Julian, fought against the Alamanni in the battle of Argentorate in 357 A.D. ${ }^{20}$ They also took part in the emperor Valentinian I's campaign against the Saxons ${ }^{21}$. According to Notitia Dignitatum, units of catafracti, catafractarii and clibanarii were stationed all over the Roman Empire, while their noticeable preponderance in the eastern provinces seems to prove that their concentration was connected with the Persian threat ${ }^{22}$.

There is a consensus among modern scholars that the chief element which distinguished catafracti and clibanarii units from other types of cavalry was the complete armour of both the horse and rider. This is confirmed by the emperor Julian's descriptions being similar in content to Ammianus Marcellinus' accounts. The two authors compare the horsemen with sculptures and they mention both iron masks covering soldier faces, as well as the protection of the whole body and limbs made of segmented armour elements accompanied by a mail. The basic offensive weapon was a long, solid spear called contus/kontós ${ }^{23}$. There is a general agreement

$1^{\text {st }}$ to $3^{\text {rd }}$ Centuries A.D., [in:] Arms and Armour..., p. 357-392. It must be stress that giving the name of catafracti to heavy armoured Sarmatian cavalry and of other peoples of the East, where the presence of heavy cavalry is confirmed, is very debatable. On this see A.М. ХАзАнов, Очерки..., p. 71-81; Т.М. КАРмов, Погребения военной знати Западного Предкавказья и проблема происхождения конниць катафрактов у Сарматов, [in:] Центральная Азия от Ахеменидов до Тимуридов: археология, история, этнология, культура. Материаль международной научной конференции, посвященной 100-летию со дня рождения Александра Марковича Белениикого (Санкт-Петербург, 2-5 Ноября 2004 года), еd. В.П. Никоноров, Санкт-Петербург 2005, р. 104-109; А.В. Симоненко, Сарматские всадники Северного Причерноморья, Санкт-Петербург 2009, р. 245-251.

17 On military reform of the emperor Gallienus see: R. Grosse, Römische Militärgeschichte von Gallienus bis zum Beginn der byzantinischen Themenverfassung, Berlin 1920, p. 15; L. De Blors, The Policy of the Emperor Gallienus, Leiden 1976, p. 26-30; B. CAmbPell, The Army [in:] CAH, vol. XII, The Crisis of Empire A.D. 193-337, ed. A.K. Bowman, P. Garnsey, A. Cameron, Cambridge 2005, p. 115-116; F.L. SÁnChez, Virtus Probi: Payments for the Battle Cavalry during the Rule of Probus (A.D. 277-278), [in:] The Impact of the Roman Army (200 B.C. - A.D. 476). Economic, Social, Political, Religious and Cultural Aspects Proceedings of the Sixth Workshop of the International Network Impact of Empire (Roman Empire, 200 B.C. - A.D. 476) Capri, March 29 - April 2, 2005, ed. L. DE BLoIs, E. Lo CAscio, Leiden-Boston 2007, p. 563-583; I. Mennen, Power and Status in the Roman Empire, A.D. 193-284, Leiden-Boston 2011, p. 193-240.

18 Scriptores Historiae Augustae, XXV, 16, 12-15, ed. E. HoHL, vol. II, Lipsiae 1965, p. 147 (cetera: SHA).

19 SHA, XXVI, 11, 18-19, vol. II, p. 157; M. Mielczarek, Cataphracti and Clibanarii..., p. 75-76.

20 Ammianus Marcellinus, XVI, 2, 5; XVI, 12, 7; XVI, 12, 63.

21 Ammianus Marcellinus, XXVIII, 5, 6.

${ }^{22}$ Cf. an. 11 above. On the development of the Roman heavy cavalry under Constantius and Julian, see the important discussion in D. Hoffman, op. cit., vol. I, Düsseldorf 1969, p. 265-279.

${ }^{23}$ Ammianus Marcellinus, XVI, 10, 8; XXV, 1, 12; Julianus, Oratio I, 37d-38a, p. 96-98; Oratio II, 57c, p. 152, [in:] The Works of Emperor Julian, ed et trans. E. Wright, vol. I, London 1915. See also J. DEN BoEFT, 
in the modern historiography that the Roman catafracti and clibanarii developed along the lines convergent at many points with those featuring the Parthian and Sasanian heavy-armoured horsemen ${ }^{24}$.

It should be stressed that there are no mentions of catafracti or clibanarii units from the second half of the $6^{\text {th }}$ to the $10^{\text {th }}$ century ${ }^{25}$. The last certain mention on the so called leontoklibanárioi appears in a Egyptian papyri from the year 546 A.D. ${ }^{26}$ It should be noted however that, in that period, heavy-armoured horsemen still existed in the Byzantine army, but they were not described as catafracti or clibanarii. These terms are not found in the Strategikon of Maurice, nor the works of Procopius, Agathias, Menander Protector, John Malalas and the other historiographical sources from the later period. It seems worth considering why did those terms disappear from the sources of the period?

Byzantine medium and heavy-armoured cavalry during the $6^{\text {th }}$ and early $7^{\text {th }}$ century is described by Procopius of Caesarea ${ }^{27}$ and, in particular, in the

J.W. Drijvers, D. Den Hengst, H.C. Teitler, Philological and Historical Commentary on Ammianus Marcellinus XXV, Leiden-Boston 2005, p. 3, 16, 23-25, 60-63, 201. Descriptions given by the emperor Julian and Ammianus Marcellinus are similar to the famous graffito from Dura Europos where we can observe heavy armoured horseman who is equipped with metal armour consisting of segmented elements and plates accompanied by a metal rings. See M.I. RostovtzefF, Graffiti, [in:] The Excavations at Dura Europos Conducted by Yale University and the French Academy of Inscriptions and Letters: Preliminary Report of Fourth Season of Work, October 1930 - March 1931, ed. P.V.C. Baur, M.I. RostovtzefF, A.R. Bellinger, New Haven 1933, p. 22; A.D.H. BIvar, Cavalry Equipment and Tactics on the Euphrates Frontier, DOP 26, 1972, p. 275 , plate 5; J. Diethart, P. Dintsis, op. cit., p. 74, plate 1; D. Nicolle, Sassanian Armies. The Iranian Empire Early $3^{\text {rd }}$ to mid-7 $7^{\text {th }}$ Centuries A.D., Stockport 1996, p. 15; S. JAMES, The Excavations at Dura Europos Conducted by Yale University and the French Academy of Inscriptions and Letters from 1928 to 1937. Final Report: The Arms and Armor and Other Military Equipment, London 2004, p. 43, plate 13. This kind of armour was very popular among the Persian heavy armoured riders. See P. Skupniewicz, Sasanian Plate Armour, FAH 19, 2006, p. 19-35. Probably this combined armour was adopted by the Romans: M.C. BIsHop, Lorica Segmentata, vol. I, A Handbook of Articulated Roman Plate Armour, London 2002, p. 73-76; A. Argüín, Una cuestión a debate: la lorica segmentata en las fronteras orientales del Imperio Romano, Gla 26, 2006, p. 105-117; M.C. BisHop, J.C. Coulston, Roman Military Equipment from the Punic Wars to the Fall of Rome, London 2006, p. 190-193; A.Е. Негин, К вопросу о защитном вооружении римских катафрактариев и клибанариев, [in:] Материалы IX чтений памяти профессора Николая Петровича Соколова: Тезисы докладов межвузовской научной конференции, Нижний Новгород, 29-30 октября 2004 г., Нижний Новгород 2004, р. 45-49.

${ }^{24}$ E. GaввA, Sulle influenze reciproche degli ordinamenti militari dei Parti e dei Romani, [in:] Atti del convegno sul tema: La Persia e il mondo Greco-romano, Roma 11-14 Aprile 1965, Roma 1966, p. 51-73; J.C. Coulston, Roman, Parthian and Sassanid Tactical Development, [in:] The Defence of the Roman and Byzantine East. Proceedings of the Colloquium Held at the University of Shiffield in April 1986, Part I, B.A.R. S297, ed. A.R. Hands, D.R. Walker, Oxford 1986, p. 59-75; J. Diethart, P. Dintsis, op. cit., p. 74; M. Mielczarek, Cataphracti and Clibanarii..., p. 85.

${ }^{25}$ E. McGeer, Kataphraktoi, [in:] ODB, vol. II, p. 1114; V.P. Nikonorov, Cataphracti, Cataphractarii, Clibanarii..., p. 137.

26 J.M. Diethart, P. Dintsis, op. cit., p. 80.

27 The literature on Procopius is vast. See e.g. B. Rubin, Prokopios von Kaisarea, Stuttgart 1954; W.E. Kaegi, Procopius, the Military Historian, BF 15, 1990, p. 53-85; A. CAmeron, Procopius and the Sixth Century, Cambridge 1996. 
Strategikon ${ }^{28}$, whose precept suggest that the influence of the Avar warfare was at this time particularly powerful ${ }^{29}$. According to Strategikon, heavy-armoured horsemen (referred as zabátoi ${ }^{30}$, not as catafracti or clibanarii) were protected by long armour called zába intended to cover them down to the ankle ${ }^{31}$. The origin of this term was probably connected with eastern cultural and military influences $^{32}$. Moreover, they also possessed a mail hoods and neck-guards, segmented helmets (probably Spangenhelme) ${ }^{33}$. The author of the treatise states explicitly that much of this equipment was modeled on the Avar panoply, in particular the neck-guard (peritrachélion), the leather thong (lorion) attached to the middle of the lance, the loose-fitting and decorated clothing and the horse armour consisted of iron or textile coverings. Cavalrymen also wore a fur coat or wide, thick felt garment (gounnion or noberoníkion) to protect them from the weather and the enemy's arrows and other kinds of weapon ${ }^{34}$. They were also equipped

28 The question of authorship of the Strategikon is debatable. In modern literature there is widespread opinion that this practical compendium for highest commanders was composed by emperor Maurice at the turn of the $6^{\text {th }} / 7^{\text {th }}$ century. See F. Aussaresses, L'auteur du Strategicon, REA 8, 1906, p. 23-39; A. Dain, J.A. De Foucault, Urbicius ou Mauricius?, REB 26, 1968, p. 123-136; A. Kambylis, Textkritische Beiträge zum Strategikon des Maurikios, JÖB 25, 1976, p. 47-56; A. KollautZ, Das militärwissenschaftlische Werk des sogennanten Maurikios, Bкa 5, 1987, p. 87-136; F.E. SHLOsser, The Reign of the Emperor Maurikios (582-602). A Reassessment, Athens 1994, p. 28-34; В. Кучма, Стратегикос Онасандра и Стратегикон Маврикийа: опыт сравнителнй характеристики, [in:] IDEм, Военная организация византийской империи, Санкт-Петербург 2001, р. 139-208; П.В. ШувАлов, Урбикий и “Стратегикон” Псевдо-Маврикия, I, BB 61, 2002, p. 71-87; IDEM, ор. сit., II, BB 64, 2005, p. 34-60. ${ }_{29}$ Mauricii Strategicon, I, 2, 19-22, 35-39, ed. et trans. G.T. Dennis, E. Gamillscheg, Wien 1981 (cetera: Strategikon) $[=\mathrm{CFHB}, 17]$. Detailed analysis of heavy cavalry equipment contained in Strategikon is given by following authors: F. Aussaresses, L’armée byzantine à la fin du VI siècle d'après le Strategicon de l'empereur Maurice, Paris 1909, passim; E. DARKó, Influences Touraniennes sur lévolution de l'art militaire des Grecs, des Romains et des Byzantins, B 12, 1937, p. 128-129; A. Pertusi, Ordinamenti militari, guerre in Occidente e teorie di guerra dei Bizantini (secc. VI-X), SSCISAM 15, 1967, p. 667-670; J.F. HALDON, Some Aspects of the Byzantine Military Technology from the Sixth to the Tenth Centuries, BMGS 1, 1975, p. 18-26; IDEM, Warfare, State and Society in the Byzantine Word 565-1204, London 1999, p. 129-130.

30 Strategikon, X, 1, 19-21; XII, B, 23.

31 Strategikon, I, 2, 10-12.

${ }^{32}$ The etymological derivation of this term is uncertain. Probably is linked with Persian-Turkish word džebe or Arabic term jubbah. Cf. E. Oldennurg, Die Kriegsverfassung der Westgoten. Inaugural-Dissertation zur Erlangung der Doktorwürde genehmigt von der Philosophischen Fakultät der Friedrich Wilhelms Universität zu Berlin, Berlin 1909, p. 43; A.D.H. Bivar, op. cit., p. 288; T.G. Kolias, Zába, Zabareion, Zabareiótes, JÖB 29, 1980, p. 27-35; IDEM, Byzantinische Waffen: ein Beitrag zur byzantinischen Waffenkunde von dem Anfängen bis zur lateinischen Eroberung, Wien 1988, p. 37-40; R. MuÑoz, El éjercito visigodo: desde sus origenes a la batalla de Guadalete, Madrid 2003, p. 27; A. NefEdkin, Armour of the Goths in the $3^{\text {rd }}-7^{\text {th }}$ Centuries A.D., FAH 19, 2006, p. 57; P.Ł. Grotowski, Arms and Armour of the Warrior Saints. Tradition and Innovation in Byzantine Iconography (843-1261), Leiden-Boston 2010, p. 126, 158-159.

33 Strategikon, I, 2, 12-13. See also T.G. Kolias, Byzantinische Waffen..., p. 63; A. Pertusi, op. cit., p. 668.

34 Strategikon, I, 2, 18-21; 35-39; 46-49. See also W. PohL, Die Awaren. Ein Steppenvolk in Mitteleuropa 567-822 n. Chr., München 1988, p. 171-172. 
with two stirrups (skálai), an innovation adopted from the Avars, who probably had carried it across from the eastern steppe and China ${ }^{35}$. The panoply was completed by a cavalry sword (spathion) and a bow (toxárion), probably of a Hunnic origin $^{36}$. Horses belonging to the highest commanders (archóntes) and elite soldiers (epilektoi), who fought in the first rank, were protected at the front by felt or iron coverings ${ }^{37}$.

It should be observed that beside the heavy-armoured cavalry, units of mounted archers (hippotoxótai) also existed in the Byzantine army. According to Procopius the best mounted archers wore breast plates, helmets and small circular shields attached to the left shoulder (very interesting feature found in Persian art). Their horses were unarmoured, since the cavalry described by Procopius functioned both as shock troops and highly mobile and effective mounted arch$\mathrm{ers}^{38}$. What is significant is that Procopius refers heavy-armoured cavalryman as tethōrakisménos, not as katáfraktos or klibanários, which is linked with the tradition of classicizing historiography ${ }^{39}$. In other sources the term thorrakofóros as a synonymous of heavy-armoured horseman is also applied ${ }^{40}$.

35 Strategikon, I, 2, 41-42; II 9, 22-28. On stirrups and its introduction see: A.D.H. BIvar, The Stirrup and its Origin, OAr 1, 1955, p. 61-65; M.A. LitTauer, Early Stirrups, An 55, 1981, p. 99-105; S. SzÁdeCZKY-Kardoss, Der awarisch-türkische Einfluss auf die byzantinische Kriegskunst um 600 (Anmerkungen zum Strategikon des Maurikios), [in:] Turkic-Bulgarian-Hungarian Relations (VI ${ }^{\text {th }}-X I^{\text {th }}$ Centuries), ed. G. KÁldy-NAgY, Budapest 1981, p. 66-69 [= Studia Turco-Hungarica, 5]; J. Werner, Ein byzantinischer Steigbügel aus Caričin Grad, [in:] Caričin Grad I. Les basiliques B et J de Caričin Grad. Quatre objets remarquables de Caričin Grad. Le trésor de Hajdučka Vodenica. Préface de Charles Pietri et Georges Vallet, ed. N. Duval, V. Popović, Rome 1984, p. 147-155; A.E. Dien, The Stirrup and Its Effect on Chinese Military History, AOr 16, 1986, p. 33-56; В.П. Никоноров, К вопросу о роли стремян в развитии военного дела, [in:] Степи Евразии в древности и Средневековье. Материалы международной научной конференции, посвященной 100-летию со дня рождения М. Гразнова, ed. М.Б. Пиотровский еt al., vol. II, Санкт-Петербург 2003, p. 263-267; F. CuRTA, The Earliest Avar Age Stirrups or the Stirrups Controversy Revisited, [in:] The Other Europe in the Middle Ages: Avars, Bulgars, Khazars and Cumans. East Central and Eastern Europa in the Middle Ages 450-1450, ed. IDEM, R. Kovalev, Leiden 2008, p. 297-327; P.Ł. Grotowsкi, op. cit., p. 379-383.

36 Strategikon, I, 2, 16-17 and 20. On Byzantine swords and its typology see A. BruHN-Hoffmeyer, Military Equipment in the Byzantine Manuscript of Scylitzes in Biblioteca Nacional in Madrid, Granada 1966, p. 91-110; М. Aleksić, Some Typological Features of Byzantine Spatha, ЗРВИ 47, 2010, p. 121-136; P.Ł. Grotowsкi, op. cit., p. 342-357; V. Yotov, A New Byzantine Type of Sword $7^{\text {th }}-11^{\text {th }}$ Century, [in:] Ниш и Византија. Девети научни скуп Ниш, 3-5 Јун 2010, ed. М. Ракоција, Ниш 2011, p. 113-124; G. Amatuccio, Peri toxeias. L'Arco da Guerra nel Mondo Bizantino e Tardo-Antico, Bologna 1996, passim. 37 Strategikon, I, 2, 35-39.

38 Procopius of Caesarea, The Persian War, I, 1, 8-16, [in:] History of the Wars, trans. H.B. Dewing, vol. I, London 1953 (cetera: Procopius); A.D.H. Bivar, Cavalry Equipment and Tactics..., plates 23, 28, 30; J.F. Haldon, Some Aspects..., p. 18; П.В. Шувалов, Секрет Армии Юстинана: Восточноримская Армиа в 491-641 г2., Санкт-Петербург 2006, р. 171-186.

39 For tethōrakisménos cf. e.g. Procopius, I, 1, 13; IV, 26, 1.

${ }^{40}$ On the term thōrakofóros/thōrakofóroi see Ph. RANCE, The Date of the Military Compendium of Syrianus Magister (Formerly the Sixth-Century Anonymus Byzantinus), BZ 100, 2007, p. 716. 
It seems to me, that Avar influence on deployment of horse armour in Byzantium is misleading by modern historiography ${ }^{41}$. As it mentioned above, Maurice draw attention to the fact, that

the horses, especially those of the high commanders and the other elite cavalrymen, in particular those in the front ranks of the battle array, should have protective pieces of iron armor about their heads and breast plates of iron or felt, or else breast and neck coverings such as the Avars use ${ }^{42}$.

The opinion based on the Maurice' description that the Avar horsemen were mainly responsible for the introduction of lamellar horse coverings into Byzantine army, is shared by J. Haldon ${ }^{43}$. It seems to me that this thesis is not convincing. It must be noted, that the horse armour of the Avar heavy cavalry is attested only in the written sources. At any rate, archeological and pictorial evidences cannot corroborate its deployment ${ }^{44}$. This opinion concerning especially the iron horse armour of which not a single example has so far been found in the archaeological material ${ }^{45}$. What is more, the archeological material strongly suggests that armour was rarely used by the Avar warriors. Probably it belonged to the noble and well-to-do nomads or tribal elite. Avar's cemeteries are characterized by the relatively high number of close-combat weapons and archery equipment ${ }^{46}$. In this context, Maurice' account concerning the Avar's horse armour must be treated with great care. It must be stressed that horse armour had been used in the Greco-Roman world at least since the days of Xenophon, and continued to be used by some elite units of the Byzantine army. Probably, the Avar horse equipment that is described by the author of Strategikon is a pastiche of Byzantine equestrian armour that was current in use from the time of the ancient catafracti and clibanarii. As we have seen, their horse armour was strongly linked with the Persian influences and it had nothing to do with the Avar military equipment ${ }^{47}$.

${ }^{41}$ W. PoHL, op. cit., p. 171-172.

${ }^{42}$ Strategikon, I, 2, 35-39.

43 J.F. Haldon, Some Aspects..., p. 22.

44 K. NAGY, Notes on the Arms of the Avar Heavy Cavalry, AO.ASH 58, 2005, p. 139.

${ }^{45}$ F. DAIM, Avars and Avar Archaeology. An Introduction, [in:] Regna et Gentes. The Relationship Between Late Antique and Early Medieval Peoples and Kingdoms in the Transformation of the Roman World, ed. H.W. Goetz, J. Jarnut, W. Pohl, S. Kashke, Leiden 2003, p. 465.

${ }^{46}$ Ibidem, p. 478-479; B. BACHRACH, A Picture of Avar-Frankish Warfare from a Carolingian Psalter of the Early Ninth Century in Light of the Strategicon, AEMA 4, 1986, p. 20; G. CsIKY, Armament and Society in the Mirror of the Avar Archaeology. The Transdanubia-Phenomenon Revisited, [in:] Studia Universitatis Cibiniensis. Series Historica VIII. Supplementum VIII. Proceedings of the First International Conference Interethnic Relations in Transylvania. Militaria Mediaevalia in Central and South Eastern Europe, Sibiu, October $14^{\text {th }}-17^{\text {th }}$, 2010, ed. I.M. Tiplic, Sibiu 2011, p. 23.

47 Seе В.П. Никоноров, Развитие конского защитного снаряжения античной эпохи, КСИА 184, 1985, p. 30-35; А.К. Нефедкин, Защитное вооружение колесничных коней на Ближнем Востоке в ахеменидский и эллинистический периоды, [in:] Античный мир. Проблемы истории и культуры. Сборник научных статей к 65-летию со дня рождения проф. Э.Д. Фролова, ед. И.Я. Фроянов, Санкт- 
What is more, the quality of the state manufactured armour and other military equipment surpassed those of most of Byzantium foes ${ }^{48}$. Manufacturing of high quality arms and armour required advanced technologies and deployment of various materials. As opposed to sedentary societies, the mobile communities of Asian nomads could only support some blacksmiths, not a specialized arms industry. So the nomads had either to import equipment which, if the large potential clientele were to be served, meant importing from the major arm-producing states like Byzantium, China and Persia, or make what they could for themselves through the imitation of selected foreign patterns ${ }^{49}$. Similar procedures were deployed by the Avars ${ }^{50}$. We have very interesting account that in 562 a small group of Avars at Constantinople was able to purchase some elements of Byzantine $\operatorname{armour}^{51}$. But it is difficult to say if among this items was horse armour and

Петербург 1998, p. 249-260, P. Bernard, Campagne de fouilles 1978 à Aï Khanoum (Afghanistan), CRAI 124, 1980, p. 452-457, plate 12; M.A. Littauer, V. Karageorghis, Note on Prometopidia, [in:] Selected Writings on Chariots, Other Early Vehicles, Riding and Harness, ed. P. Raulwing, Leiden 2002, p. 525-530; M.A. Littauer, J.H. Crouwel, Ancient Iranian Horse Helmets? [in:] Selected Writings..., p. 534-545; В.П. Никоноров, К вопросу о парфянском настедии..., р. 161.

48 Armour and other military equipment for heavy cavalry in Late Roman Empire was produced in fabricae clibanariae - state workshops established by emperor Diocletian in Daphne (Antioch) and Nicomedia. Cf. V.P. Nikonorov, Cataphracti, Cataphractarii, Clibanarii..., p. 132; R. MacMullen, Inscription of Armor and the Supply of Arms in the Roman Empire, AJA 64, 1960, p. 31. On Late Roman/ Byzantine state factories, distribution of arms and metallurgy see S. JAMES, The Fabricae: State Arms Factories of the Later Roman Empire, [in:] Military Equipment and The Identity of Roman Soldiers: Proceedings of the Fourth Roman Equipment Military Conference, ed. J.C. Coulston, Oxford 1988, p. 257-331; D. Woods, The Ownership and Disposal of Military Equipment in the Late Roman Army, JRMES 4, 1993, p. 55-65; Les listes de préséance de IXe et $X^{e}$ siècle, ed. N. Oıкоnomides, Paris 1972, p. 317; 338; P.Ł. Grotowsкi, op. cit., p. 19-26; T. G. Kolias, Zába..., p. 31-34; J.F. Haldon, The Organization and Support of an Expeditionary Force: Manpower and Logistics in the Middle Byzantine Period, [in:] Byzantium at War ( $9^{\text {th }}-12^{\text {th }}$ Century), ed. K. Tsinakes, Athens 1997, p. 119, 142-143; M.K. Papathanassiou, Metallurgy and Metalworking Techniques, [in:] The Economic History of Byzantium. From the Seventh through the Fifteenth Century, ed. A.E. LaIou, vol. I, Washington 2002, p. 121-127.

49 J.M. Sмith, The Nomads' Armament: Home-Made Weaponry, [in:] The Nomads Armament, Religion, Customary Law and Nomadic Technology. Papers presented at the Central and Inner Asian Seminar University of Toronto, 1 May 1998 and 23 April 1999, ed. M. Gervers, W. Schlepp, Toronto 2000, p. 53-54. See also U. JÄGER, Sogdian or Sasanian Types of Armament in Vendeltime Sweden? A Question to be Asked Once Again, [in:] Military Archaeology: Weaponry and Warfare in the Historical and Social Perspective. Materials of the International Conference 2-5 September 1998, ed. G.V. Vilnibahov et al., Saint Petersburg 1998, p. 309. ${ }_{50}$ On Avar metallurgy as synthesis of different technics and foreign influences (especially from Byzantium) see O. HeInRICH-Tamaska, Avar-Age Metalworking Technologies in the Carpathian Basin ( $6^{\text {th }}$ to $8^{\text {th }}$ Century), [in:] The Other Europe in the Middle Ages: Avars, Bulgars, Khazars and Cumans. East Central and Eastern Europa in the Middle Ages 450-1450, ed. F. CurTa, R. Kovalev, Leiden 2008, p. 237-263. On the role of Avars in spreading of Eastern forms of armament in Europe see O. GAMber, Chinese Warriors and Avars, [in:] Military Archaeology: Weaponry and Warfare..., p. 186-187; W. ŚWIĘTOSŁAWSKI, Rola Awarów w rozpowszechnieniu w Europie azjatyckich form uzbrojenia, AUL.FA 23, 2001, p. 75-85.

${ }^{51}$ Menander Protector, Excerpta de legationibus gentium ad Romanos, fr. 4, [in:] Excerpta historica iussu imperatoris Constantini Porphyrogeniti confecta, ed. C. DE Boor, Berlin 1903. 
could the information concerning this event had served as the basis for Maurice description $^{52}$.

Nevertheless, one should observe, that the heavy and medium cavalry equipment shows marked steppe influence, as well as an influence of the Sasanian cavalry tactics and panoply. The early-seventh century bas-relief in Persia at Taq-iBustan shows king Khosrow II (590-628) in armour remarkably similar to that ascribed to the ancient catafracti and clibanarii and heavy cavalrymen by the Strategikon. The king's horse is covered by what appears to be a lamellar armour made from metal or leather elements $s^{53}$. We can find similarly armoured horsemen in Persian $\operatorname{art}^{54}$. According to this evidence, a conclusion seems authorized, that the construction, material and use of the individual elements of weapons and armour used by the Byzantine heavy-armoured horsemen of the $6^{\text {th }}$ and $7^{\text {th }}$ centuries compared to those of the ancient catafracti and clibanarii proves that the Byzantine heavy-armoured cavalry was a continuation of the latter, not necessarily in respect of the formation identity or tactics, but more so in respect of the arms used and of other elements of the equipment. Although the terms catafracti and clibanarii were not used at that time, the heavy armoured cavalry still existed.

I suppose, that disappearance of these terms from the sources was connected with great changes that took place in military technology and ethnic character of the Byzantine army ${ }^{55}$. Through various intermediary peoples who inhabited or passed through the steppe regions north of the Danube and the Black Sea the Byzantine Empire maintained regular contacts with more distant societies, as a result of which elements of military panoply or practices originating from Central Asia

\footnotetext{
52 B. BACHRACH, A Picture of Avar-Frankish Warfare..., p. 20-21.

53 M. MichalaK, op. cit., p. 82-83; K. Tanabe, An Identification of the Chain-Armoured Equestrian Image at the Larger Grotto Taq-i Bustan, O 17, 1981, p. 105-118; M. Mode, Art and Ideology at Taq-i Bustan: The Armoured Equestrian, [in:] Arms and Armour as Indicators of Cultural Transfer. The Steppes and the Ancient World from Hellenistic times to the Early Middle Ages, ed. IDEM, J. Tubach, Wiesbaden 2006, p. 393-415. On Late Sasanian horse armour and weapon see remarks in В.Ю. Вдовин, В.П. Никоноров, Фрагменты панцирного доспеха позднесасанидского времени из Тоголок-депе, НСо 4, 1991, p. 77-79; D.T. Роттs, Late Sassanian Armament from Southern Arabia, [in:] Electrum. Studies in Ancient History, ed. E. DĄBRowA, vol. I, Cracow 1997, p. 127-137; IDEM, A Sasanian Lead Horse from Northeastern Arabia, IA 28, 1993, p. 193-199; P. SkUPNIEwICZ, Shafted Weapons of Sasanian Hunting Iconography, FAH 22, 2009, p. 49-64.

${ }^{54}$ M. MichalaK, op. cit., p. 82.

55 See J. Haldon, Byzantine Praetorians. An Administrative, Institutional and Social Survey of the Opsikion and Tagmata, c. 580-900, Bonn 1984, p. 139-141; IDEM, Administrative Continuities and Structural Transformations in East Roman Military Organization c. 580-640, [in:] IDEM, State, Army and Society in Byzantium. Approaches to Military, Social and Administrative History, $6^{\text {th }}-12^{\text {th }}$ Centuries, Aldershot 1995, p. 9-11; O. Sснмітт, Untersuchungen zur Organization und zur militärischen Stärke oströmischer Herrschaft im Vorderem Orient zwischen 628-633, BZ 94, 2001, p. 216-228; R. SCHARF, Foederati. Von der völkerrechtlichen Kategorie zur byzantinischen Truppengatung, Wien 2001, p. 100-126; F.R. TROMBLEY, Military Cadres and Battle During the Reign of Heraclius, [in:] The Reign of Heraclius (610-641). Crisis and Confrontation, ed. J. Reinink, B.H. Stolte, Groningen 2002, p. 241-261.
} 
or even from further East permeated into the Balkans, Asia Minor and Middle East $^{56}$. For example, the stirrups were adopted from the Avars, and the appearance of the single-edged sabre in the $8^{\text {th }}$ or $9^{\text {th }}$ century can be connected with the Khazars or Magyars ${ }^{57}$. There is no need to argue that a large amount of archaeological material and a number of descriptions of the Byzantine soldiers in various military treatises confirm that ${ }^{58}$. Simultaneously with the development of the military technology a great deal of new terminology of Persian, Germanic and Eastern origin applying to military equipment and tactics appears in the Greek language. For example, such loanwords as bándon, foúlkon, zába, etc. are attested ${ }^{59}$. As we have seen, the term catafracti was not used at this time however. Probably, it could have been simply forgotten or replaced by other terms connected with the new military technology. For example, the zabátos as a significant, new term used to describe heavy armoured horseman or kaballários from the Latin caballarius, one of several words used in Byzantine written sources to designate the horseman generally. We must also remember that Byzantine chroniclers and writers were not interested in technical aspects concerning the military organization and equipment. Probably they saw no necessity to provide his readers with such details. Moreover, another solution to the question seems to be possible. Throughout the period from the $6^{\text {th }}$ century heavy-armoured cavalry supported by mounted archers played the role of a main striking force ${ }^{60}$. Thus, there was no need to emphasize its elitist character, as was the case in antiquity.

56 D. Nicolle, No Way Overland? Evidence for Byzantine Arms and Armour on the $10^{\text {th }}-11^{\text {th }}$ Century Taurus Frontier, [in:] IDEM, Warriors and their Weapons around the Time of The Crusades. Relationships between Byzantium, the West and the Islamic World, Aldershot 2002, p. 133; Г.В. Куварев, Влияние военного искусства и комплекса вооружения центральноазиатских кочевников в Европе (в свете переселения авар и создания Первого Тюркского каганата), [in:] Роль номадов.., p. 86-110; P. SCHreIner, Zur Ausrüstung des Kriegers in Byzanz, dem Kiever Russland und Nordeuropa nach bildlichen und literarischen Quellen, [in:] Les Pays du Nord et Byzance (Scandinavie et Byzance). Actes du colloque nordique et international de byzantinologie tenu à Upsal 20-22 Avril 1979, ed. R.W. Zeitler, Uppsala 1981, p. 215-236.

57 J. Haldon, Some Aspects..., p. 31-32; V. Iотоv, A Note on the Hungarian Sabres of Medieval Bulgaria, [in:] The Other Europe..., p. 327-339.

58 J.-P. Sodini, La contribution de larchéologie à la connaissance du monde byzantin (IVe-VII siècles), DOP 47, 1993, p. 168-169; G. DaGron, Ceux d’en face: les peoples étrangers dans les traités militaires byzantins, TM 10, 1987, p. 210; J. Drauschke, Zur Herkunft und Vermittlung „byzantinischer Importe“der Merowingerzeit in Nordwesteuropa, [in:] Zwischen Spätantike und Frühmittelalter. Archäologie des 4. bis 7. Jahrhunderts im Westen, ed. S. BRATHER, Berlin-New York 2008, p. 367, 372, 376-383.

59 T.G. Kolias, Tradition und Erneuerung im frühbyzantinischen Reich am Beispiel der militärischen Sprache und Terminologie, [in:] L'Armée Romain et les barbares du III ou VII s., ed. F. VALlET, M. KAZANSKI, SaintGermain-en-Laye 1993, p. 39-44; Ph. RANCE, The Fulcum, the Late Roman and Byzantine Testudo: The Germanization of Roman Infantry Tactics?, GRBS 44, 2004, p. 305-308; H. Kahane, R. Kahane, The Western Impact on Byzantium: The Linguistic Evidence, DOP 36, 1982, p. 130; P. AMORY, People and Identity in Ostrogothic Italy 489-554, Cambridge 1997, p. 102-108.

${ }^{60}$ On the rise of both types of cavalry in the period see I. Syvänne, The Age of Hippotoxotai. Art of War in Roman Military Revival and Disaster (491-636), Tampere 2004, p. 39, 118-194, 345; M.A. KarantABias, 
However, in the $10^{\text {th }}$ century, in the contemporary military treatises and other written sources, there appeared once again the term katáfraktoi (katáfraktoi kavallárioi) as a definition of heavy-armoured elitist cavalry units. In my opinion, the appearance of this term in the $10^{\text {th }}$ century might be linked with a general revival of ancient learning and culture at that time. In modern historiography this cultural process is described as the so called "Macedonian renaissance" characterized also by a great development of military science in the Byzantine Empire. Initiated by the emperor Leo VI (886-912) and continued by his son Constantine VII and his successors, a revival of military science, connected obviously with the great age of Byzantine conquest, resulted in a large corpus of classical and contemporary manuals discussing the art of war in its many dimensions ${ }^{61}$. In the specialist literature on the subject, there is a widespread opinion that the major part of military treatises of the epoch mirrors mostly the retrospective character of the work of their compilers. E. McGeer emphasizes that almost all the Byzantine military writers lacked direct experience of war, so their knowledge, drawn from the authorities of the past, was theoretical rather than practical and literary rather than techni$\mathrm{cal}^{62}$. Furthermore, concerning our topic, he argues that there was no continuous tradition of heavy cavalry in Byzantium and there were barely periodic attempts to revive this type of riders at different times, and against different enemies ${ }^{63}$. He believes, as well as some other scholars, that appearance of heavy armoured katáfraktoi in Byzantium was linked with emperor Nikephoros Phocas' military reforms ${ }^{64}$. I think, this thesis is very debatable. I try to show, that the Byzantine katáfraktoi were not only modeled on their ancient predecessors, but they even constituted a full continuation of the ancient formation. They applied the same tactical procedures and were equipped with similar armour as their ancient forerunners. According to this evidence we could draw the conclusion, that the "Macedonian renaissance" had also practical influence on the Byzantine warfare in the $10^{\text {th }}$ century.

\footnotetext{
The Crucial Development of Heavy Cavalry under Herakleios and His Usage of Steppe Nomad Tactics, Hir 4, 2005/2006, p. 28-41.

61 A. DAIn, La tradition des stratègistes byzantins, B 20, 1950, p. 315-316, J. IRIGoIN, Survie et renouveau de la littérature antique à Constantinople (IX'siècle), CCM 5, 1962, p. 287-302; A. DAIN, Les stratégistes byzantins, TM 2, 1967, p. 317-392; P. LEMERLE, Le premier humanisme byzantin. Notes et remarques sur enseignement et culture à Byzance des origines au Xe siècle, Paris 1971, p. 267-301; H. Hunger, Die Hochsprachliche Profane Literatur der Byzantiner, vol. I, München 1978, p. 323-340; A. Cutler, A. Kazhdan, Continuity and Discontinuity in Byzantine Culture, B 52, 1982, p. 429-478; G. DAGron, H. MihăEscu, Commentaire, [in:] Le traité sur la guérilla (De velitatione bellica) de l'empereur Nicéphore Phocas (963-969), ed. et trans. IIDEM, Paris 1986, p. 139-145, 153-160; В. Кучма, Византийские военные трактаты VI-X вв. как исторические источники, [in:] IDEм, Военная организация..., p. 43-54.

${ }^{62}$ E. McGeer, Sowing the Dragon's Teeth: Byzantine Warfare in the Tenth Century, Washington 2008, p. 171.

${ }^{63}$ Ibidem, p. 317-318.

${ }^{64}$ A. Toynbee, Constantine Porphyrogenitus and His World, London 1973, p. 311-313; H.J. Kunn, Die Byzantinische Armee im 10. und 11. Jahrhundert: Studien zur Organization der Tagmata, Wien 1991, p. 127-128.
} 
Besides the katáfraktoi, in Byzantine army of that time new formations described by ancient names like athánatoi ('immortals'), peltàstai (light infantry) and hoplitai (heavy-armoured infantry) were also present ${ }^{65}$. Its appearance was strongly connected with the revival of ancient patterns which took place in $10^{\text {th }}$ century. In this context, the Byzantine military writers employed the word katáfraktoi because this was the term favored by the late Hellenistic and Roman military literature. Since it existed in antiquity, this term was used by the authors of the tenth-century military treaties to denote a specific class of heavy cavalry ${ }^{66}$.

For the first time since the late antiquity the term katáfraktoi appears in the anonymous treatise on strategy called Peri strategías or the Military Compendium of Syrianus Magister perhaps written no in the $6^{\text {th }}$ century (a sixth-century date proposed by G.T. Dennis is no longer tenable) but rather in the $9^{\text {th }}$ century or even later ${ }^{67}$. According to this source, the heavy armoured katáfraktoi were placed on the either side of solid infantry formation ${ }^{68}$. What is more, we can find detailed description of arms and armour of heavy armoured horsemen. They should be equipped with iron armour for their heads, breasts and necks. Theirs horses should be covered (katafrássein) in the same manner. Author recommends, that the "soles" of the horses' hooves should also be likewise protected with iron plates (petála) so that they will not easily be injured by caltrops (tribóloi) and other devices ${ }^{69}$. The term katáfraktoi is also present in the tactical constitutions of the emperor Leo VI when he describes heavy - armoured cavalry of the ancient period as well as units contemporary to him ${ }^{70}$. The author reports that the chief element which distinguished the units of katáfraktoi from other types of cavalry (mè katáfraktoi) is the complete armour of both horse and warrior ${ }^{71}$. Unfortunately, his descrip-

65 R. D’Amato, Gli Athanatoi, guardia del corpo dellimperatore Giovanni Tzimiskès, Porph 4, 2007, p. 54-56; E. McGeer, Sowing the Dragon's Teeth..., p. 203-206. The peltàstai and hoplitai are described in: Leonis VI Tactica, V, 2; VI, 29, 32, ed. et trans. G.T. Dennis, Washington 2010 (cetera: Leo VI) [= CFHB, 49]; Sylloge Tacticorum quae olim Inedita Leonis Tactica dicebatur, XXXVIII; XXX, 4; XXXVIII, 6, ed. A. Dain, Paris 1938 (cetera: Sylloge Tacticorum). On peltasts in antiquity see analysis given by J.P.G. BRest, Thracian Peltasts and Their Influence on Greek Warfare, Groningen 1969.

${ }_{66} \mathrm{Ph}$. Rance, The Date..., p. 715-716.

67 G.T. Dennis, The Anonymous Byzantine Treatise on Strategy. Introduction, [in:] Tres Tractatus Byzantini De Re Militari, ed. and trans. IDEM, Washington 2008, p. 1-7 [= CFHB, 25]; F. LAMmERT, Die älteste erhaltene Schrift über Seetaktik und ihre Beziehung zum Anonymus Byzantinus des sechsten Jahrhunderts zu Vegetius und zu Aineias' Strategika, K 33, 1940, p. 271-288. On the contrary opinion see: B. BALDwin, On the Date of the Anonymous Peri Strategikes, BZ 81, 1988, p. 290-293; A.D. LEe, J. ShePARD, A Double Life: Placing the Peri Presbeon, Bsl 52, 1991, p. 15-39; C. Zuckerman, The Compendium of Syrianus Magister, JÖB 40, 1990, p. 209-224; S. Cosentino, The Syrianos's Strategikon: a Ninth Century Source? Bi 2, 2000, p. 248-261; Ph. RANCE, The Date..., p. 719-737.

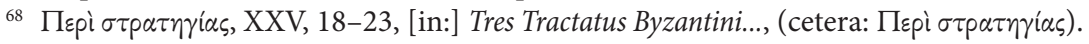

${ }^{69}$ Пврі $\sigma \tau p \alpha \tau \eta \gamma i \alpha$, XVII, 12-19. On caltrops see Leo VI, V, 4-5.

${ }^{70}$ Leo VI, VI, 25-27. See also Ad Leonis Augusti Tactica Appendix, XXXIII, XXXIX, [in:] PG, vol. CVII, ed. et trans. J.-P. Migne, Paris 1863, col. 1097-1098, 1105-1106.

${ }^{71}$ LeO VI, VI, 26-27. 
tion concerns only the military equipment which applied to this heavy-armoured horsemen, not to the tactical procedures. Probably the lack of such information was linked with the emperor's scanty military experience ${ }^{72}$. Nevertheless, we possess an excellent description of the tactics and equipment of such heavy-armoured horsemen. Detailed description of the ancient and Byzantine cataphracts' equipment contains the anonymous military manual knowing as Sylloge Tacticorum ${ }^{73}$. The Byzantine katáfraktoi are also described by the emperor Nicephorus Phocas and by a famous military commander the time, Nicephorus Uranos. We must draw attention to the fact, that both were experienced military leaders, which means, that their descriptions are very reliable ${ }^{74}$. According to their accounts the Byzantine katáfraktoi were the best equipped soldiers in the army. Their compact helmets were fitted with a complete guards of mail or textile two or three layers thick, pierced only with eye holes ${ }^{75}$. This was a style long knowing in the East $^{76}$. The torso was protected by a klibánion. This term demands a careful attention. It may

72 We must draw attention to the fact that the practical value of Leo's work is difficult to gauge. On this see A. Vogt, La Jeunesse de Léon VI le Sage, RH 174, 1934, p. 408; P. Karlin-Hayter, When Military Affairs Were in Leo's Hands: A Note on Foreign Policy (886-912), T 23, 1967, p. 20. But on the other hand it must be stressed that he was interested in military matters. See S. Tougher, The Imperial ThoughtWorld of Leo VI: The Non Campaign Emperor of the Ninth Century, [in:] Byzantium in the Ninth Century. Dead or Alive? Papers from the Thirtieth Spring Symposium of Byzantine Studies, Birmingham, March 1996, ed. L. BRUBAKER, London 1998, p. 51-63. On the date and composition of the treatise see K.E. ZACHARIÄ VON Lingenthal, Zum Militärgesetz des Leo, BZ 2, 1893, p. 606-608; G. MoravCsiK, La Tactique de Léon VI le Sage comme source historique hongroise, AH.ASH 1, 1952, p. 161-184; S. Tougher, The Reign of Leo VI (886-912). Politics and People, Leiden-New York-Köln 1997, p. 166-172. There is no need to argue that the core of the tactical constitution is a reprise of Maurice and ancient sources. Leo's alterations suggest that he did not fully understand aspects of Maurice's text especially in those places were the tactics of different kinds of units are described, what indicates that author's theoretical and practical military knowledge was scanty. On this see P. RANCE, The Fulcum..., p. 315-321.

${ }_{73}$ Sylloge Tacticorum, XXXI, 1-3; XXXIII, 1; XXXIX, 1-6; XLVI, 6-7. On the authorship of the Sylloge Tacticorum see E. McGeer, Sylloge Tacticorum, [in:] ODB, vol. III, p. 1980.

74 R. VÁRI, Die Praecepta Nicephori, BZ 30, 1929/1930, p. 49-53; H. MiHĂEscu, Pour une nouvelle édition du traité Praecepta militaria du Xe siècle, RSBS 2, 1982, p. 315-322; E. MCGEER, Tradition and Reality in the Taktika of Nikephoros Ouranos, DOP 45, 1991, p. 129-140; F. Trombley, Taktika Nikephorou tou Ouranou and Military Encyclopaedism, [in:] Pre-modern Encyclopaedic Texts. Proceedings of the Second COMERS Congress, Groningen, 1-4 July 1996, ed. P. BinkLey, Leiden 1997, p. 261-274; E. MCGeER, Sowing the Dragon's Teeth..., p. 80-81, 171-196.

75 Nicephori Praecepta Militaria ex codice Mosquensi, 11, 13-15, ed. Ю.А. КулАковский, ЗИАН.ИФО

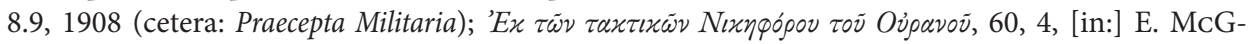
EER, Sowing the Dragon's Teeth..., (cetera: NICEPhorus Uranos); Sylloge Tacticorum, XXXIX, 3. See also J. Haldon, Some Aspects..., p. 37; T.G. Kolias, Byzantinische Waffen..., p. 63, 76-77; P.Ł. Grotowski, op. cit., p. 158-159.

${ }^{76}$ H.R. Robinson, Oriental Armour, London 1967, p. 21-22; A.D.H. Bivar, op. cit., p. 290, plate 30; D.G. Alexander, Two Aspects of Islamic Arms and Armor, BMMA 18, 1984, p. 97-104; J. Diethart, P. Dintsis, op. cit., p. 72-73, plate 4, 5 and 7; R. D'Amato, op. cit., p. 60; A. Zouache, L'armement entre Orient et Occident au VI'/XII siècle. Casques, masses d’armes et armures, AIs 41, 2007, p. 286, 291-294. 
stem from the Persian griwbān ('neck armour' or 'hauberk'; literally 'something that connects a helmet with the rest of the armour'). The appearance of this word in antiquity was linked with the rise of clibanarii units. Probably in the $3^{\text {rd }}$ century this foreign term was adopted into everyday soldiers speech and became latinised. In Roman sources the loanword was employed to designate the heavy-armoured horseman, the clibanarius $^{77}$. But on the other hand the hypothesis on Greek and Latin origin of this term not be excluded. This term being derived from Latin word clibanum (Gr. klíbanos) not in the sense as 'oven' but as something like 'a fuller armour suit'. From this term derive such words as clibanariil klibanárioi, klibánion, klibanátos ('covered in armour') ${ }^{78}$. We can observe that the etymology of klibánion was straightforwardly linked with the ancient clibanarii/klibanárioi. In the Byzantine military manuals from the $10^{\text {th }}$ century the klibánion might refer to as little as the breast and back, but could also mean a full armour consisting of breast and back, shoulder guards, sleeves and skirt or even a horse armour ${ }^{79}$. This is confirmed by Nicephorus Phokas who stipulates, that the klibánia of the katáfraktoi should have sleeves and skirt coverings (kremásmata) $)^{80}$. This term has been interpreted as skirt-like coverings which protected the rider from the waist to the $\mathrm{knee}^{81}$. This is echoed by Nicephorus Uranos in his Tactica ${ }^{82}$. The klibánion referred to anything made of lamellar, such as horse armour. In this period Byzantine craftsmen had introduced a technological innovation in lamellar construction ${ }^{83}$. In the generic lamellar armour known from Persia, China and other civilizations, the plates overlap and are tied together horizontally before the rows are assembled vertically ${ }^{84}$.

\footnotetext{
77 O. Fiebiger, Clibanarii, RE IV, 1, 1899, p. 22; F. RUNDGRen, Über einige iranische Lehnwörter im lateinischen und griechischen, OSu 6, 1957, p. 49-51; M. MicHALAK, op. cit., p. 76-77; A.D.H. BIVAR, op. cit., p. 277-278, 291; A. TAFAzzoli, A List of Terms for Weapons and Armour in Western Middle Iranian Dedicated to Professor A.D.H. Bivar, SRAA 3, 1993/1994, p. 187-188; M.M. KHoraSAni, Linguistic Terms Describing Different Types of Armor in Persian Manuscripts, Gla 30, 2011, p. 160.

78 V.P. Nixonorov, Cataphracti, Cataphractarii, Clibanarii..., p. 132; Lexicon zur Byzantinische Gräzität, ed. E. Trapp, vol. I, p. 840. We can observe that in the paraphrase of the Strategikon of emperor Maurice, which constituted a part of the so-called Codex Ambrosianus Graecus prepared using materials from the library of Constantine VII Porphyrogenitus around 959, the term zabátos was replaced by the word klibanatos. This change might be connected with great revival of the ancient military science. See B. Leoni, La Parafrasi Ambrosiana dello Strategicon di Maurizio, XIIb, 23, 16, Milano 1997.

79 Leo VI, VI, 4; Sylloge Tacticorum, XXXIX, 1; Praecepta Militaria, 11, 7, 16-22; NicePhorus Uranos, 60, 4-5. See also T.G. Kolias, Byzantinische Waffen..., p. 44-49; J. Haldon, Some Aspects..., p. 30-35; P.Ł. Grotowski, op. cit., p. 129.

${ }^{80}$ Praecepta Militaria, 11, 8-9.

${ }^{81}$ T. Dawson, Kremásmata, Kabádion, Klibánion: Some Aspects of Middle Byzantine Military Equipment Reconsidered, BMGS 22, 1998, p. 42-43; E. McGeen, Sowing the Dragon's Teeth..., p. 215-216.

${ }^{82}$ Nicephorus Uranos, 60, 4.

83 T. Dawson, Suntagma Hoplon: The Equipment of Regular Byzantine Troops c. 950 to c. 1204, [in:] A Companion to Medieval Arms and Armour, ed. D. Nicolle, Suffolk 2002, p. 84-85.

${ }^{84}$ On lamellar armour and its history see: B. Thordeman, P. Nörlund, B.E. Ingelmark, Armour from the Battle of Wisby 1361, vol. I, Stockholm 1939, p. 245-285; Ю.С. Худяков, Вооружение
} 
The new method did not tie the plates to each other, but instead attached them side by side to the leather backing. This kind of armour was highly effective in resisting cuts, but was also proof against axe and mace blows ${ }^{85}$. Over their corselets the katáfraktoi wore padded thick armour (epilórikion) made of course of silk or cotton ${ }^{86}$. According to military manuals this coverings were a solid protection against penetrative blows and impacts ${ }^{87}$. Graves (chalkótouba) and armguards (manikélia) completed their protective armour ${ }^{88}$. They also carried shields to be protected against enemies' arrows ${ }^{89}$. The weapons of the katáfraktoi were designed for use in combat at close quarters. Most carried an iron maces, (siderorabdía) others carried swords and spears ${ }^{90}$.

Our sources indicate, that the katáfraktoi must have possessed powerful, bold horses $^{91}$. In the Middle Byzantine period the heavy-armoured horsemen used horses mainly Anatolian breeds, taken from the regions highly developed in horsebreeding as Phrygia, Cappadocia and Syria where the imperial stables were placed,

\footnotetext{
центральноазиатских кочевников в эпоху раннего и развитого Средневековья, Новосибирск 1991, passim; G.V. Kubarev, Der Panzer eines alttürkischen Ritters aus Balyk - Sook, EAn 3, 1997, p. 629-645; W. ŚwiĘTOSŁAWski, Arms and Armour of the Nomads of the Great Steppe in the Times of the Mongol Expansion (12 $2^{\text {th }}-14^{\text {th }}$ Centuries), Łódź 1999, p. 21-25; A. DiEn, A Brief Survey of Defensive Armour Across Asia, JEAA 2, 2000, p. 1-22; Yu.S. KhudyAKov, S.A. Bobrov, Reconstruction of Central Asian Nomadic Defensive Arms, FAH 19, 2006, 46-52; G.V. KuBAREv, Die Schützwaffen mit figürlichen Lamellen als Indikator der Nomadenmigration in Eurasiens Steppenzone im 6-8 Jh., [in:] Arms and Armour as Indicators..., p. 453-484; T. Dezsö, The Reconstruction of the Neo-Assyrian Army as Depicted on the Assyrian Palace Reliefs 745-612 B.C., AAr.ASH 57, 2006, p. 87-130. On the archeological finds of this kind of armour discovered on Byzantine estates from $6^{\text {th }}$ to $12^{\text {th }}$ century see P. BEATson, Byzantine Lamellar Armour: Conjectural Reconstruction of a Find from Great Palace in Istanbul based upon Early Medieval Paralells, VaV 49, 1998, p. 3-8; I. Bugarski, A Contribution to the Study on Lamellar Armours, Ста 55, 2006, p. 161-179; J. Vizcaíno SÁnchez, Early Byzantine Lamellar Armour from Carthago Spartaria (Cartagena, Spain), Gla 28, 2008, p. $195-210$.

85 T. Dawson, Klibánion Revisited: An Evolutionary Typology and Catalogue of Middle Byzantine Lamellar, JRMES 12/13, 2001, p. 18-36, M. PARANI, Reconstructing the Reality of Images: Byzantine Material Culture and Religious Iconography (1 $1^{\text {th }}-15^{\text {th }}$ Centuries), Leiden-Boston, 2003, p. 104-111; P.Ł. GrotowsKI, op. cit., p. 137-151; R. D’Amato, A Prôtospatharios, Magistros, and Strategos Autokrator of $11^{\text {th }}$ Century: The Equipment of Georgios Maniakes and His Army According to the Skylitzes Matritensis Miniatures and Other Artistic Sources of the Middle Byzantine Period, Porph 2005, Suppl. 4, p. 15-17; M. Tsurtsumia, The Evolution of Splint Armour in Georgia and Byzantium. Lamellar and Scale Armour in the $10^{\text {th }}-12^{\text {th }}$ Centuries, B $\Sigma$ u 21, 2011, p. 65-99.

${ }^{86}$ Praecepta Militaria, 11, 10-12; T.G. Kolias, Byzantinische Waffen..., p. 59-61; P.Ł. Grotowsкi, op. cit., p. 177-179, 307-309.

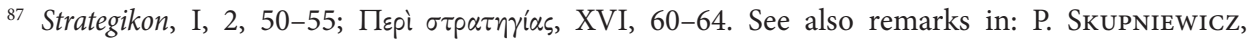
O ciężkozbrojnej jeździe Sasanidów, AUNC.H 379, 2006, p. 157-158.

88 Praecepta Militaria, 11, 8, 15; Nicephorus Uranos, 60, 4; J. Haldon, Some Aspects..., p. 37.

89 Sylloge Tacticorum, XXXIX, 1; Praecepta Militaria, 11, 23; Nicephorus Uranos, 60, 5.

90 Sylloge Tacticorum, XXXIX, 4-6; Praecepta Militaria, 11, 33; 12, 2; Nicephorus Uranos, $60,7$.

91 Praecepta Militaria, 11, 16; Nicephorus Uranos, 60, 5.
} 
as well as Persian horses ${ }^{92}$. The Alexiad of Anna Comnena contains very interesting account concerning the Thessalian mounts belonged to the Thracian and Macedonian heavy-armoured riders ${ }^{93}$. Horses of the Byzantine katáfraktoi were also covered in armour ${ }^{94}$. But we should bear in mind, that in the East armour has never been as heavy as in Western Europe. The hotter climate, the generally lighter build of men and horses and the greater value attached to the mobility required lighter armour ${ }^{95}$. The author of Praecepta Militaria confirm this. He describes two kinds of caparisons. One was made from quilted felt or pieces of hardened leather fastened together and covering the horse's head and the rest of his body down to the knees ${ }^{96}$. This kind of armour was light but very resistant. It effectiveness is confirmed by the vivid relation of Theophanes. He describes emperor Heraclius' personal combat in a charge against the Persian cavalry near Niniveh on 12 December 626. Dórkōn, the horse belonging to the emperor, was wounded in the thigh by some infantryman who struck it with a spear. It also received several sword blows on the head, but, wearing a full quilted felt armour described as katáfrakta neurikà, he was not hurt; the blows were ineffective ${ }^{97}$. The other part of armour mentioned in Praecepta Militaria was made from bison hides and likewise covered the horse's body ${ }^{98}$. Ac-

92 A. Hyland, The Medieval Warhorse from Byzantium to the Crusades, Stroud 1994, p. 18-53, 85; J. HaLDon, Commentary, [in:] Constantini Porphyrogeniti Tres Tractatus de Expeditionibus Militaribus Imperatoris, ed. et. trans. IDEM, Wien 1990, p. 80, 120, 161, 170, 184-185, 239 [= CFHB, 28]; IDEM, Warfare, State and Society..., p. 141; J.W. Birkenmeyer, The Development of Komnenian Army 1081-1180, Leiden-Boston-Köln 2002, p. 172. See also P. Magdalino, The Chartoularata of Northern Greece in 1204, [in:] The Despotate of Epeiros, ed. E. Chrysos, Arta 1992, p. 31-34.

93 Annae Comnenae Alexias, I, 5, 2, ed. D.R. Reinsch, A. Kambylis, vol. I, Berolini 2001 (cetera: AnNA Comnena) [= CFHB, 40]. See also A. Hohlweg, Beiträge zur Verwaltungsgeschichte des oströmischen Reiches unter den Komnenen, München 1965, p. 80-82.

${ }_{94}$ Leo VI, VI, 8, 26; Sylloge Tacticorum, XXXIX, 6. On deployment of the horse armour in antiquity see H. YANG, Lamellar Armor and Horse Bardings in Yamato and Koguryo and Their Connections with China, JEAA 2, 2000, p. 123-137; B. LAufer, Chinese Clay Figures, vol. I, Prolegomena on the History of Defensive Armor, Chicago 1914, p. 218-222, 306-315 [= Publications of the Field Museum of Natural History. Anthropological Series, 13.2]; F. Grenet, J.C. Liger, R. DE VAlence, L'Arsenal, BEFEO 68, 1980, p. 60-63. Сf. Б.Б. ОвчинниковА, К вопросу о вооружении кочевников средневековой Тувы (по материалам могильника Аймырлыг), [in:] Военное дело древних племен..., p. 141-142, and an. 47 above.

95 S.V. Grancsay, The New Galleries of Oriental Arms and Armor, BMMA 16, 1958, p. 241-242; R.H.C. Davis, The Warhorses of the Normans, ANSt 10, 1988, p. 67-82; A. Hyland, op. cit., p. 57-59, 62-63, 83-99, 117-118; J. Clark, The Size of the Medieval Horse, [in:] The Medieval Horse and Its Equipment c. 1150 - c. 1450, ed. IDEM, London 1995, p. 22-32; J. FranCE, Technology and Success of the First Crusade, [in:] War and Society in the Eastern Mediterranean $7^{\text {th }}-15^{\text {th }}$ Centuries, ed. Y. LEv, Leiden 1997, p. 165; A. Ayton, Arms, Armor and Horses, [in:] Medieval Warfare. A History, ed. M. Keen, Oxford 1999, p. 190-192; J. France, Crusading Warfare and its Adaptation to Eastern Conditions in the $12^{\text {th }}$ Century, MHR 15, 2000, p. 51,

96 Praecepta Militaria, 11, 16-22; Nicephorus Uranos, 60, 5.

97 Theophanis Chronographia, A.M. 6118, rec. C. DE Boor, vol. I, Lipsiae 1883, p. 318, 25-28; F.R. Trombley, Military Cadres..., p. 246. On this kind of felt covering see also Leo VI, XIX, 13.

${ }_{98}$ Praecepta Militaria, loc. cit. 
cording to Leo VI among the Byzantine heavy-armoured cavalry there were also present riders who, as in antiquity, rode on the horses which were covered in metal armour. This kind of carapace was made from plates or scales ${ }^{99}$. It was however very expensive and on account of this was prescribed to only wealthy, high ranking commanders.

The description of arms and armour of katáfraktoi given by Nicephorus Phocas and Nicephorus Uranos is similar to the accounts of ancient authors, like Ammianus Marcellinus, who describes the Roman cataphracti as Praxiteles' sculptures, emperor Julian and Heliodorus. That habitant of Emesa, from a family of the descendants of Helios is the author of a Greek novel entitled Ethiopian stories. His account is very interesting:

The character of their armament is the following. A selected man wears a helmet that is compact and made of one piece, and it is skillfully crafted like a man's face. He is covered by it from the top of his head to the neck except for the eyes in order to see through it; he equips his right hand with a pike longer than a spear, the left is free for the reins (...). He is armed with a corselet not only across his breast but also across the rest of his body (...). They fence their horses all around with similar equipment, tying graves around the feet, and they bind the whole head tightly with frontlets, and from the back to the belly they suspend on either side a covering plaited in iron (...). When the moment of battle comes $(\ldots)$ he is looking like an iron man or like a moving image wrought with the hammer. ${ }^{100}$

There are reasons to believe that in the Byzantine times as well as in the antiquity, the performance of katáfraktoi on the battlefields played a considerable part in grinding down the enemies' morale. According to Leo the Deacon the Rus' warriors were frightened by them and they were so demoralized, that they became incapable of fighting against the "ironclad horsemen" (pansíderoi hippótai) in battle ${ }^{101}$. Moreover, the poem composed by an Arab writer al-Mutanabbi records the Arabs' amazement at the sight of the cavalrymen who advanced on horses which seemed to have no legs and whose helmets and garments were of iron like their swords ${ }^{102}$. This evidence is very similar to those given by Ammianus Marcellinus, Julian and Heliodorus. We must bear in mind, that this heavy-armoured horsemen, like in antiquity, represented the elite of the Byzantine army, which probably consisted of wealthy aristocrats and theirs re-

\footnotetext{
99 LEO VI, loc. cit.

${ }^{100}$ Héliodore, Les Éthiopiques, IX, 15, 1-6, ed. R.M. Rattenbury, T.W. Lumb, Paris 1960. See also B. Dignas, E. Winter, Rome and Persia in Late Antiquity. Neighbours and Rivals, Cambridge 2007, p. 63-64; M.H. Dodgeon, G. Greatrex, S.N.C. Lieu, The Roman Eastern Frontier and the Persian Wars (AD 226-363). A Documentary History, London-New York 2002, p. 183-184.

${ }^{101}$ Leonis Diaconi Caloënsis Historiae Libri Decem et Liber de Velitatione Bellica Nicephori Augusti, IX, 8, ed. et trans. C.B. Hase, Bonnae 1828 (cetera: Leo Diacon); E. McGeer, Sowing the Dragon's Teeth..., p. 316.

102 A.A. VAsilev, Byzance et les Arabes. La Dynastie Macédonienne (867-959). Extraits des sources arabes, ed. et trans. M. Canard, Bruxelles 1950, p. 333, 16.
} 
tainers ${ }^{103}$. The numbers cited in the Praecepta Militaria and Tactica of Uranos indicates that an army of twenty-five thousand men contained no more than 504 or 384 katáfraktoi. So, this formation was not numerous ${ }^{104}$. The presence of the retainers and squires is confirmed by the terms klibanofóroi and epilorikofóroi mentioned in short novel prepared under the name of the emperor Nicephorus II Phokas ${ }^{105}$. If the interpretation of this words as "armour bearers" is correct, it provides explanation that this novel refers to an increase in the number of squires in the service of the elite cavalry troops, which meant that each warrior would normally have to provide no less than two orderlies accompanying him on campaign ${ }^{106}$.

Nicephorus Phocas refers to the formation used by the katáfraktoi as a triangle or rather solid wedge. The triangular formation of the katáfraktoi was the centerpiece in the front line of the Byzantine forces. This array was very simple and easy to create. It stood twelve rows deep with each row adding two men to either sides as the formation went back, thereby increasing the total of men in successive rows by four at a time. During the battle the first four lines were to be composed of katáfraktoi wielding iron maces, a very hard shock weapon; from the fifth row to the twelfth, the two horsemen on each sides alternated with lancers or cavalrymen armed with swords or maces. In the middle of the triangle there were mounted archers protected within the surrounding the array of heavy - armoured horsemen ${ }^{107}$.

The tactics prescribed by Nicephorus Phocas and echoed by Uranos is corroborated by Leo the Deacon, who mentions the katáfraktoi several times ${ }^{108}$. At the battle of Tarsus in 965 the katáfraktoi stood in the front line between units of horsemen led by Nicephorus Phocas on the right wing and John Tzimiskes

\footnotetext{
${ }^{103}$ See an. 85 above.

${ }^{104}$ E. McGeer, Sowing the Dragon's Teeth..., p. 217.

${ }^{105}$ Les novelles des empereurs macédoniens concernant la terre et les stratiotes, X, 15-22, ed. et trans. N. Svoronos, Athènes 1994, p. 176. See also H. AhrweIler, Recherches sur l'administration byzantin aux IX ${ }^{e}-X I^{e}$ siècles, [in:] EADEM, Études sur les structures administratives et sociales de Byzance. Préface par Paul Lemerle, London 1971, p. 16.

${ }^{106}$ P. Magdalino, The Byzantine Army and the Land: From Stratiotikon Ktema to Military Pronoia, [in:] Byzantium at War ( $9^{\text {th }}-12^{\text {th }}$ Century), ed. K. Tsinakes, Athens 1997, p. 21-23. On the contrary opinion see J. HALdon, Recruitment and Conscription in the Byzantine Army c. 550-950. Studies on the Origin of the stratiotika ktemata, Wien 1979, p. 43-44; E. MCGEER, The Land Legislation of the Macedonian Emperors, Toronto 2000, p. 107-108, an. 7; T.G. KolIAs, Ein zu wenig bekannter Faktor im byzantinischen Heer: die Hilfskräfte (paides, pallikes, hypourgoi...), [in:] Polypleuros nous. Miscellanea für Peter Schreiner zu seinem 60. Geburtstag, ed. G. Sсносн, G. MaKris, Leipzig 2000, p. 122-123.

${ }^{107}$ Sylloge Tacticorum, XLVI, 6-7; Praecepta Militaria, 10, 15-33; 11, 1-4, 24-29; 12, 4-7; Nicephorus Uranos, 60, 1-3, 6, 8. See also E. McGeer, Infantry versus Cavalry: The Byzantine Response, REB 46, 1988, p. 135-147; IDEM, The Syntaxis armatorum quadrata: a tenth-century tactical blueprint, REB 50, 1992, p. 219-229; IDEM, Sowing the Dragon's Teeth..., p. 286.

${ }^{108}$ Leo Diacon, IV, 3; V, 2; VIII, 9; IX, 8.
} 
on the left. The use of archers from behind the advancing heavy-armoured cavalry is also in accordance with the emperors' directive to have mounted archers inside the wedge-column order ${ }^{109}$. Leo the Deacon also records the katáfraktoi in action during John Tzimiskes' wars against the Rus. According to this account, at the battle of Dorostolon in July 971 emperor John Tzimiskes placed the "ironclad horsemen" (pansíderoi hippótai) on either wing of the battle array, but, as Nicephorus Phocas previously remarked, he also placed the archers behind them ${ }^{110}$. There is a strong similarity between Leo the Deacon account and description of heavy armoured cavalry tactics given by the anonymous author of the Peri strategías ${ }^{111}$.

As we have seen, the Byzantine katáfraktoi in $10^{\text {th }}$ century applied the same tactical procedures as their ancient forerunners by fighting in the wedge-shaped order, which is ascribed to the ancient clibanarii. Moreover, as in antiquity, in the $10^{\text {th }}$ century this type of heavy-armoured cavalry was accompanied by mounted archer units. This array, defined as cuneus was created in antiquity. According to the classical tactician Arrian, the cavalry wedge had been invented by the Scythians who passed it on to the Thracians from whom it was adopted by Philip III of Macedonia ${ }^{112}$. In the next centuries this kind of battle order was perfected in practice by the Roman cavalry. Therefore one must emphasize that the revival of ancient military treatises in Byzantium had not only a theoretical, but also a practical importance. What is more, we can draw the conclusion that heavy armoured cavalry always existed in Byzantine Empire. Military reforms which took place in the second half of the $10^{\text {th }}$ century didn't create this formation. As we have seen, the term katáfraktoi is attested much earlier than military reforms were introduced.

According to E. McGeer, during the subsequent centuries, the role of heavilyarmoured cavalry decreased. He thinks that katáfraktoi became completely useless, especially in the western part of Byzantine Empire, because the author of De re

\footnotetext{
${ }^{109}$ Leo Diacon, IV, 3; E. McGeer, Sowing the Dragon's Teeth..., p. 314-315.

${ }^{110}$ Leo Diacon, VIII, 9; E. McGeer, Sowing the Dragon's Teeth..., p. 316. On the battle at Dorostolon see S. McGrath, The Battles of Dorostolon (971). Rhetoric and Reality, [in:] Peace and War in Byzantium: Essays in Honor of George T. Dennis, S.J., ed. T. Miller, J. Nesbitt, Washington 1995, p. 152-164. On this war see D. AnASTAsiejvić, La chronologie de la guerre russe de Tzimiscès, B 6, 1931, p. 337-342; F. DöLGer, Die Chronologie des grossen Feldzuges des Kaisers Johannes Tzimiskes gegen die Russen, BZ 32, 1932, p. 275-292; H. GrÉGOIRE, La dernière campagne de Jean Tzimiscès contre les Russes, B 12, 1937, p. 267-296; П.О. КАРышковский, О хронологии русско - византийской войны при Святославе, ВВ 5, 1952, p. 127-138, ІDEм, Балканскийе войны Святослава в византийской исторической литературе, BB 6, 1953, p. 36-71.

${ }^{111}$ See Пврі $\sigma \tau p \alpha \tau \eta \gamma$ í, XXV, 18-23.

112 Arrian, Ars Tactica, XVI, 6-8, [in:] Flavii Arriani quae extant omnia. Scripta minora et fragmentata, ed. et trans. A.G. Roos, G. Wirth, vol. II, Lipsiae 1968. See also A.M. Devine, Embolon - A Study in Tactical Terminology, Phoe 37, 1983, p. 201-217; E.W. MARsden, The Campaign of Gaugamela, Liverpool 1964, p. 68-73; E. McGeER, Sowing the Dragon's Teeth..., p. 288.
} 
militari, who focuses mainly on the northwestern frontiers of the empire, makes no mention of them. The mountainous, wooded terrain of the Balkans denied them the level ground they needed to perform effectively their tactics. Moreover, emperor Basil II's strategy hinged more on control of key routes, passes and strongholds, a type of warfare that elevated the role of infantry and light cavalry as opposed to confrontations in the open field suited to heavy cavalry. Like all heavy cavalry, the katáfraktoi were a very expensive formation which employed ponderous, inflexible tactics that required intensive training and ideal conditions to succeed. Finally, E. McGeer concludes, that katáfraktoi probably passed out of use by the early eleventh century ${ }^{113}$.

I think, that this opinion is not convincing. According to our sources katáfraktoi were still a useful military force. Nicephorus Uranos, an experienced military leader who supervised the eastern frontier from Antioch, recommends that the detachment of 150 katáfraktoi accompanying a raid into the enemy lands be accompanied by an infantry force trailing in the wake of the more mobile cavalry units sent ahead in search of prisoners and plunder. He also proposes that forty or fifty katáfraktoi may leave their armour and their horses' carapaces and participate in the raid as light horsemen. As we can observe the tactics of the katáfraktoi was completely changed, what proves, that katáfraktoi were a universal formation and their presence on the battlefields was of essential importance ${ }^{114}$. Moreover, the authors of the eleventh and twelfth century sources emphasize that the regular heavy cavalry continued to be a key element in the Byzantine army. At the battle of Troina in Sicily, in 1040, the Byzantine heavyarmoured horsemen demolished the Arab array at the first attack ${ }^{115}$. According to Michael Psellus, when Constantine IX Monomachus celebrated his victory over George Maniaces in 1043, the elite heavy cavalry armed with shields, spears, bows and swords, described as katáfraktoi hippoi, took part in the tri$u^{u m p h}{ }^{116}$. The same author stresses that katáfraktoi constituted the main striking force of Leo Tornicus army in $1047^{117}$. Detachments of heavy-armoured cavalry, known as katáfraktoi, also appear in the Alexiad of Anna Comnena. We must draw attention to the fact, that Anna Comnena uses this term when she describes native Byzantine heavy cavalry (doryfóroi katáfraktoi) as well as western knights in the Byzantine service (Kéltoi katáfraktoi) ${ }^{118}$. Heavy-armoured katá-

\footnotetext{
${ }^{113}$ E. McGeer, Sowing the Dragon's Teeth..., p. 317-318.

${ }^{114}$ Nicephorus Uranos, 63, 3.

${ }^{115}$ Account mentioned above comes from unpublished Life of St. Philaretus the Younger (BHG 1513), an eleventh-century saint of Byzantine Calabria (ca. 1020-1076). Cited after Ph. Rance, The Date..., p. $730-731$.

${ }^{116}$ Michael Psellos, Chronographie ou histoire d'un siècle de Byzance (976-1077), ed. et trans. E. ReNauld, vol. II, Paris 1928 (cetera: Michael Psellus), LXXXVII, 6-11, p. 7.

${ }^{117}$ Michael Psellus, CVII, 18-24, p. 20.

${ }^{118}$ Anna Comnena, II 8, 5; V 5, 2; V 6, 4; XIII 5, 3; XIV 6, 3; XV 6, 4; XV 6, 7.
} 
fraktoi were present on the battlefields during the Comnenian period. Thanks to John Cinnamus, we possess an excellent description of the tactical organization of the Byzantine forces before the battle outside Constantinople's walls in September 1147:

They were organized as follows: the most unwarlike common part of the army stood far forward in four units, thereafter, the well armed and mounted, after these came those riding swift footed horses, and finally, at the back of the army were the Scythians and Persians as well as the Roman archers. Thus, the least warlike ones formed a screen in front of the whole army, behind them stood the katáfraktoi, the heavy-armoured cavalry. ${ }^{119}$

Unfortunately, we lack a detailed description of the battle, we only know, that the Byzantines were victorious. Nevertheless, it is noteworthy, that the light cavalry and mounted archers were positioned in back of the heavy-armoured katáfraktoi. Similarly as in the $10^{\text {th }}$ century, the formation of the katáfraktoi was placed in the centre of the battle array of the Byzantine army.

To sum up. As we have seen, in the specialist literature on the subject, there is a widespread opinion that the heavily-armoured elite cavalry, defined as catafracti and clibanarii had existed from the Hellenistic period until the end of Late Antiquity. Whereas a comparison of the construction, material and use of the individual elements of weapons and armour used by the Byzantine heavy cavalry from the sixth century and the first half of the seventh century with those of the ancient catafracti and clibanarii, allows us to draw the conclusion that the Byzantine heavily armed cavalry was its continuation, not necessarily in respect of the identity of the formations and their tactics, but more so in respect of the arms in use and other elements of equipment. The term catafracti was not used at that time. Classifying the Byzantine cavalry from this period as catafracti, despite the fact that it is not usually defined in this way is based on the opinion of emperor Leo VI, expressed in Tactica, in accordance with which the chief element which distinguished catafracti and clibanarii units from other types of cavalry was the complete armour of both the horse and rider. In spite of the fact that the Romans, in response to the Sasanid heavy cavalry, created their own mailed cavalry described by names catafracti or clibanarii, the influence of the Steppe peoples (principally the Huns and Avars) was more pronounced in the next centuries. Their weapons and tactics completely transformed the Byzantine way of war. In particular, this development concerned the cavalry - the main striking force of Byzantine army at this time. As we have seen, a disappearance of the ancient terms catafracti and clibanarii and their tactics (fighting in wedge-column order) was linked with this process of change.

${ }^{119}$ Ioannis Cinnami epitome rerum ab Ioanne et Alexio Comnenis gestarum, II, 15, ed. et trans. A. MeINEKe, Bonnae 1836; J.W. BirKenMeYeR, op. cit., p. 109-110. 
In the $10^{\text {th }}$ century, in contemporary military treatises the term katáfraktoi appeared once again, a fact that can be connected with a usage typical for the "Macedonian renaissance". At this time, the elitist formations of this type constituted a force marginal as compared to other cavalry units making up the Byzantine forces. However, the appearance of the $10^{\text {th }}$ century katáfrakto $i$ was a practical effect of the revival of ancient traditions in the Byzantine culture: they were not a formation which was only modeled on its ancient predecessor, but its constituted a continuation of the ancient patterns. The cavalry were equipped with protective armour similar to that of their ancient forerunners. They also applied the same tactics, for instance by fighting in the wedge-column order, which is ascribed to the ancient cavalry of this type. The sources mentioned above indicate that this kind of battle array was reintroduced at this time. Moreover, the katáfraktoi were also present as a main striking cavalry force in the Comnenian army, which indicates that heavy-armoured cavalry was still necessary. There is no reason to doubt the opinion that there was a continuous tradition of heavy-armoured cavalry in the Byzantine Empire.

\begin{abstract}
This article discusses the question of origin and identity of katáfraktoi - heavy-armoured cavalry in Byzantium. In the specialist literature on the subject, there is a widespread opinion that the heavily-armoured elitist cavalry, defined as catafracti and clibanarii had existed from the Hellenistic period until the end of Late Antiquity. Whereas a comparison of the construction, material and use of the individual elements of weapons and armour used by the Byzantine heavy cavalry from the sixth century and the first half of the seventh century with those of the ancient catafracti and clibanarii, allows us to draw the conclusion that the Byzantine heavily armed cavalry was its continuation, not necessarily in respect of the identity of the formations and their tactics, but more so in respect of the used arms and other elements of equipment. The term catafracti was not used at that time. Classifying the Byzantine cavalry from this period as catafracti, despite the fact that it is not usually defined in this way is based on the opinion of emperor Leo VI, expressed in Tactica, in accordance with which the chief element which distinguished catafracti and clibanarii units from other types of cavalry, was the complete armour of both the horse and rider. In spite of the fact, that the Romans, in response to the Sasanid heavy horsemen created their own mailed cavalry described by names catafracti or clibanarii, the influence of the Steppe people (principally the Huns and Avars) was more pronounced in the next centuries. Their weapons and tactics completely transformed the Byzantine way of war. In particular, this development concerned the cavalry - the main striking force of Byzantine army at this time. As we have seen, a disappearance of the ancient terms catafracti and clibanarii and their tactics (fighting in wedge-column order) was linked with this process of change.

In the $10^{\text {th }}$ century, in contemporary military treatises the term katáfraktoi appeared once again, a fact that can be connected with a usage typical for the "Macedonian renaissance". At this time, the elitist formations of this type constituted a force marginal as compared to other cavalry units making up the Byzantine forces. However, the appearance of the $10^{\text {th }}$ century katáfraktoi were a practical effect of the revival of ancient traditions in the Byzantine culture: they were not a formation which was only modeled on its ancient predecessor, but its constituted a continuation of the ancient patterns. The horsemen were equipped with similar protective armour as their ancient forerunners. They also applied the same tactics, for instance by fighting in the wedge-column order, which is ascribed to the ancient cavalry of this type. Sources mentioned above indicates, that this kind of battle array was
\end{abstract}


reintroduced at this time. Moreover, the katáfraktoi were also present as a main striking cavalry force in the Comnenian army, which indicates, that heavy-armoured cavalry was still necessary. There is no reason to accept the opinion that there was no continuous tradition of heavy-armoured cavalry in the Byzantine Empire.

Michał Wojnowski

36-213 Haczów 496

Polska

michal.wojnowski@vp.pl 